\title{
Antidepressants and Mood Stabilizers: Novel Research Avenues and Clinical Insights for Bipolar Depression
}

\author{
In Hee Shim ${ }^{1}$, Young Sup Woo ${ }^{2}$, Moon-Doo Kim ${ }^{3}$ and Won-Myong Bahk ${ }^{2, *}$ \\ 1 Department of Psychiatry, Cancer Center, Dongnam Institute of Radiological \& Medical Sciences, \\ Busan 46033, Korea; ihshim1224@gmail.com \\ 2 Department of Psychiatry, College of Medicine, The Catholic University of Korea, Seoul 07345, Korea; \\ youngwoo@catholic.ac.kr \\ 3 Department of Psychiatry, School of Medicine, Jeju National University, Jeju 63241, Korea; \\ mdkim66@jejunu.ac.kr \\ * Correspondence: wmbahk@catholic.ac.kr; Tel.: +82-2-3779-1250
}

Received: 29 September 2017; Accepted: 9 November 2017; Published: 13 November 2017

\begin{abstract}
The concept of the bipolar-spectrum and of mixed features being a bridge between major depressive disorders and bipolar disorders (BDs) has become increasingly important in mood-disorder diagnoses. Under these circumstances, antidepressants (ADs) and mood stabilizers (MSs) should be used with caution in the treatment of major depressive episodes (MDEs) and to obtain long-term stability in BDs. Before treating MDEs, screening tools, specific symptom evaluation and medical history should be used to distinguish between bipolarity and mixed features in patients for whom AD monotherapy may present a risk. In these patients, a combination of ADs plus MSs or atypical antipsychotics is recommended, rather than AD monotherapy. Studies evaluating MSs for bipolar depression suggest that lamotrigine is the most reliable treatment and lithium has modest effects; there is a lack of clear evidence regarding the efficacy of valproate and carbamazepine. Recently, significant progress has been made with respect to the pathophysiology of mood disorders and the application of potential biomarkers. There is an opportunity to study novel drug mechanisms through the rediscovery of fast-acting drugs such as ketamine. It is anticipated that future research developments will involve the discovery of potential targets for new drugs and their application to personalized treatments.
\end{abstract}

Keywords: antidepressant; mood-stabilizer; lithium; depression; mixed features; major depressive episode; bipolar disorder

\section{Introduction}

Recent preliminary evidence suggests a potential trans-nosological effect of selected atypical antipsychotics (AAPs) beyond only psychotic disorders. Treatment with antipsychotics is an effective augmentation option for major depressive disorders (MDDs), bipolar mania and depression. For cases of non-psychotic depression with no response to the initial treatment strategy, some guidelines suggest augmentation of treatment with an AAP such as aripiprazole or quetiapine [1-3]. In the past, the preferred initial treatment strategy for mania, regardless of type, was MSs plus AAPs; however, recently, AAP monotherapy has been considered the most effective first-line treatment [4-6]. AAP monotherapy is recommended for mildly severe bipolar depression, while AAPs combined with mood stabilizers (MSs) or antidepressants (ADs) are recommended for moderate to severe depression $[4,7]$. 
Despite the increasing use of AAPs, MSs continue to play an important role in the management of bipolar mania and depression. Most mood disorders are characterized by the onset of a major depressive episode (MDE), and AD monotherapy is typically the first-line treatment. However, for bipolar disorders (BDs), AD monotherapy is very rarely recommended despite the high prevalence of depressive episodes. The risk-benefit profile of AD monotherapy for BDs remains controversial. Most guidelines suggest ADs as an adjuvant therapy with MSs [8], as a short-term rather than long-term treatment [9]. The proper use of MSs with ADs is very important during the acute phase of MDEs and the maintenance phase of BDs.

This review provides an overview of standard AD and MS treatments for both the acute phase of MDEs and long-term stabilization of BDs.

\section{Comparison of MDEs in MDDs and BDs}

For MDEs, it is difficult to distinguish between MDDs and BDs based on the clinical symptoms alone. The Diagnostic and Statistical Manual of Mental Disorder (DSM) and the International Classification of Disease diagnostic criteria for the two disorders are very similar. In research and in clinical practice, assessments of symptom severity and changes in symptoms are conducted using the same methods (e.g., the Hamilton Depression Rating Scale (HAMD) or the Montgomery-Asberg Depression Rating Scale (MADRS)). Because most patients with BDs present with the onset of a MDE, one-half to two-thirds of patients are initially misdiagnosed $[10,11]$. More than one-third remain misdiagnosed for 5-10 years or more [12,13].

Although there are many similarities between unipolar and bipolar depression, there are a number of significant differences. Patients with MDDs typically report more somatization and affective symptoms such as anxiety, anger, and agitation, and less anhedonia [14]. Contrarily, patients with bipolar depression tend to experience more atypical symptoms such as hypersomnia, hyperphagia, and leaden paralysis, as well as psychomotor retardation, psychotic features, pathological guilt, and lability of mood, although there are no pathognomonic biomarkers or clinical characteristics [15]. Regarding the long-term course of these illnesses, patients with bipolar depression are more likely to have an earlier age of onset [16], more prior episodes of depression [17], shorter depressive episodes [18], a family history of BDs [19], comorbid substance use disorder [20], and a higher risk of postpartum depression [21].

In the past, most treatment strategies were based on the type of mood disorder and episodic polarity, which were differentiated early in treatment. However, recent diagnostic and treatment approaches have focused on transdiagnostic psychopathology, spectrum, and dimensional classifications. The process reflecting the tendency of these changes is shown in Figure 1. First, a syndromal concept, such as bipolar-spectrum disorder including bipolar I, II, and not otherwise specified (NOS) and mixed features presenting subthreshold hypo (manic) symptoms (although DSM-5 criteria for bipolar-spectrum disorder or mixed features specifier no longer met) should be checked at the beginning of MDE treatment. Careful assessment of bipolar symptoms using screening instruments (e.g., the hypomania checklist (HCL-32)), mood depression questionnaires (MDQs), screening assessment of depression-polarity (SAD-P)) or mental status examinations, patient history and clinical course, and family history is crucial to treatment decisions [22]. In addition, symptomatic (HAMD, MADRS, Young Mania Rating Scale (YMRS)) and functional (premorbid occupational and daily life functioning status) aspects must be evaluated [23]. 


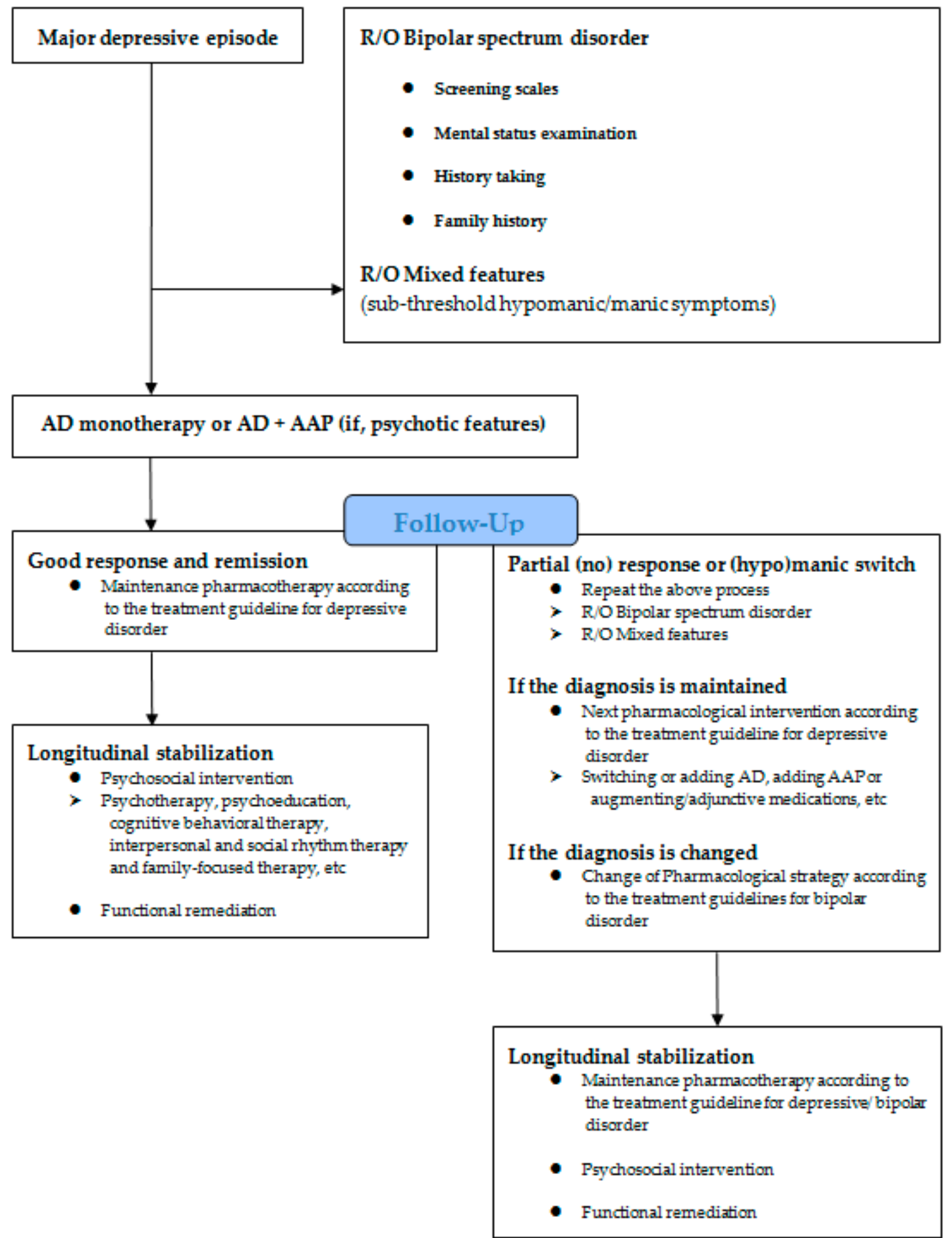

Figure 1. Treatment of major depressive episodes and the longitudinal stabilization of mood disorder. (Abbreviations: AD, antidepressant; AAP, atypical antipsychotics; MS, mood stabilizer). 


\section{ADs}

\subsection{AD Monotherapy}

According to most clinical guidelines, AD monotherapy is recommended as the first-line treatment for non-psychotic MDEs without hypomanic or manic symptoms [1,3,24,25]. Newer AD agents, such as selective serotonin reuptake inhibitors (SSRIs) and serotonin-norepinephrine reuptake inhibitors (SNRIs) are preferred over older treatments [4]. These early stage MDEs usually require consideration of MDDs clinically first and follow the MDD treatment algorithms.

Studies evaluating prescription patterns indicate that ADs are prescribed for more than $50 \%$ of patients with bipolar depression [26,27]. Several randomized trials have found AD monotherapy to be an effective and safe treatment for bipolar depression; however, most of the studies were limited by small sample sizes, short durations, or lack of a control group [28-30]. The EMBOLDEN II trial found that paroxetine significantly improved HAMD scores, particularly in patients who had a good response and who had not used ADs previously [31].

AD monotherapy during the acute phase of a MDE must be administered carefully, as the response to ADs differs between MDD and BD patients. When ADs are used to treat bipolar depression, adverse effects may include mood switches, irritability, and agitation, even if not to the extent of mood switching; they can accelerate episode frequency or induce rapid cycling, and can increase the risk of suicide behaviors [8]. There is a limited role for ADs as an adjunctive therapy to MSs or AAPs for treating the acute phase of bipolar depression.

\subsection{Efficacy and Safety of ADs}

A meta-analysis of the efficacy and safety of ADs for bipolar depression revealed inconsistent results. One study indicated statistically significant overall efficacy of ADs in acute bipolar depression, while another reported that there was only a trend for higher response rates in patients treated with ADs [32,33].

Table 1 lists randomized controlled trials (RCTs) that evaluated ADs as a treatment for acute depression in BDs. Fluoxetine plus olanzapine (OFC) was the most effective treatment, while results for other ADs varied. Treatment with OFC was significantly more effective than olanzapine alone or the placebo in treatment of bipolar I depression, without increasing the risk of manic symptoms [34]. In another study, OFC was found more effective than lamotrigine for the treatment of bipolar I depression, although some increases in metabolic factors were observed [35]. Contrarily, paroxetine, bupropion, and agomelatine adjunctive therapies did not differ from the placebo or MS treatments [31,36,37]. 
Table 1. Randomized controlled trials of antidepressant use in acute phase in bipolar depression

\begin{tabular}{|c|c|c|c|c|c|c|}
\hline Study & $\begin{array}{l}\text { Number of Bipolar } \\
\text { Subjects (Type) }\end{array}$ & Duration (Weeks) & $\begin{array}{c}\text { Antidepressant vs. } \\
\text { Comparators (Doses, mg/d) }\end{array}$ & Primary Outcome Evaluation & Efficacy of Responders/Cases & Mood Switching \\
\hline \multicolumn{7}{|c|}{ TCAs } \\
\hline $\begin{array}{l}\text { Bochetta et al., } \\
1993[38]\end{array}$ & 30 (BP I \& II) & 4 & $\begin{array}{l}\text { Amitriptyline } 55 \pm 10 \text { vs. } \\
\text { L-sulpiride } 62 \pm 13 \\
\quad \text { add-on lithium }\end{array}$ & $\begin{array}{c}\text { Response rate } \\
(\geq 50 \% \text { reduction from baseline } \\
\text { HAMD) }\end{array}$ & $\begin{array}{l}\text { Amitriptyline } 86 \% \text { vs. } \\
\text { L-sulpiride } 93 \% ; \\
\text { no significant differences }\end{array}$ & $\begin{array}{l}\text { Only L-sulpiride } 1 \\
\text { patients }\end{array}$ \\
\hline $\begin{array}{c}\text { Agosti and } \\
\text { Steward, } 2007 \text { [39] }\end{array}$ & 70 (BP II) & 6 & $\begin{array}{l}\text { Imipramine } 50-300 \text { vs. } \\
\text { Phenelzine } 15-90 \text { vs. } \\
\text { Placebo }\end{array}$ & Responders (CGI-I 1 or 2) & $\begin{array}{c}\text { Imipramine } 56.5 \% \text { vs. } \\
\text { Phenelzine } 52 \% \text { vs. } \\
\text { Placebo } 22.7 \% ; \\
\text { no comparison within BP, } \\
\text { only BP vs. UP comparison }\end{array}$ & None \\
\hline \multicolumn{7}{|c|}{ MAO inhibitors vs. TCAs } \\
\hline $\begin{array}{l}\text { Himmelhoch et al., } \\
1991 \text { [40] }\end{array}$ & 56 (BP I \& II) & 6 & $\begin{array}{l}\text { Tranylcypromine } 20-60 \text { vs. } \\
\text { Imipramine } 100-300\end{array}$ & $\begin{array}{l}\text { CGI score of }+2 \text { or }+3 \text { for at } \\
\text { least } 2 \text { weeks }\end{array}$ & $\begin{array}{l}\text { Tranylcypromine } 81 \% \text { vs. } \\
\text { Imipramine } 48 \% ; \\
\text { Tranylcypromine }>\text { imipramine }\end{array}$ & $\begin{array}{l}\text { Tranylcypromine } 12 \% \text { vs. } \\
\text { Imipramine } 24 \%\end{array}$ \\
\hline $\begin{array}{l}\text { Thase et al., } \\
1992[41]\end{array}$ & 16 (BP I \& II) & 6 & $\begin{array}{l}\text { Tranylcypromine }>30 \text { vs. } \\
\text { Imipramine }>150 ; \\
\text { Crossover study, vice versa } \\
\text { in those non-responding in } \\
\text { the initial study }(101)\end{array}$ & $\begin{array}{l}\text { Unclear (BDI; HAM-D; } \\
\text { Pittsburgh reversed vegetative } \\
\text { symptom scale) }\end{array}$ & $\begin{array}{l}75 \% \text { for Imipramine to Tranylcypromine vs. } \\
25 \% \text { for Tranylcypromine to Imipramine; } \\
\text { no mention of significance }\end{array}$ & $\begin{array}{l}1 / 4 \text { patients in } \\
\text { imipramine }(25 \%)\end{array}$ \\
\hline $\begin{array}{l}\text { Silverstone, } \\
2001[42]\end{array}$ & 156 (BP I \& II) & 8 & $\begin{array}{l}\text { Moclobemide } 450-750 \text { vs. } \\
\text { Imipramine } 150-250\end{array}$ & Change from baseline HAMD & $\begin{array}{l}\text { Moclobemide } 9.9 \% \text { vs. } \\
\text { Imipramine } 13.0 \% \text {; } \\
\text { no significant difference }\end{array}$ & $\begin{array}{l}\text { Moclobemide } 3.7 \% \text { vs. } \\
\text { Imipramine } 11 \%\end{array}$ \\
\hline \multicolumn{7}{|c|}{ SSRIs vs. placebo } \\
\hline $\begin{array}{l}\text { Cohn et al., } \\
1989[43]\end{array}$ & 89 (BP I \& II) & 6 & $\begin{array}{l}\text { Fluoxetine } 20 \text { to } 80 \text { vs. } \\
\text { Imipramine } 75 \text { to } 300 \text { vs. } \\
\text { Placebo }\end{array}$ & $\begin{array}{l}\text { Response rate ( }>50 \% \text { reduction } \\
\text { from baseline HAMD) }\end{array}$ & $\begin{array}{c}\text { Fluoxetine } 86 \% \text { vs. } \\
\text { Imipraime } 57 \% \text { vs. } \\
\text { Placebo } 38 \% \text {; } \\
\text { Fluoxetine > placebo, } \\
\text { fluoxetine > imipramine }\end{array}$ & $\begin{array}{l}\text { Fluoxetine } 0 \% \text { vs. } \\
\text { Imipramine } 6.7 \% \text { vs. } \\
\text { Placebo } 3.4 \%\end{array}$ \\
\hline $\begin{array}{l}\text { Nemeroff et al., } \\
2001[44]\end{array}$ & 117 (BP I \& II) & 10 & $\begin{array}{l}\text { Paroxetine } 20-50 \text { vs. } \\
\text { Imipramine } 50-300 \text { vs. } \\
\text { Placebo; add-on lithium }\end{array}$ & $\begin{array}{l}\text { Change from baseline HAMD } \\
\text { and CGI-I }\end{array}$ & $\begin{array}{l}\text { Paroxetine } 45.5 \% \text { vs. Imipramine } 38.9 \% \text { vs. } \\
\text { Placebo } 34.9 \% \text {; no significant difference }\end{array}$ & $\begin{array}{l}\text { Paroxetine } 0 \% \text { vs. } \\
\text { Imipramine } 7.7 \% \text { vs. } \\
\text { Placebo: } 2.3 \%\end{array}$ \\
\hline $\begin{array}{l}\text { Tohen et al., } \\
2003 \text { [34] }\end{array}$ & 833 (BP I) & 8 & $\begin{array}{l}\text { Fluoxetine } 25-50 \text { vs. } \\
\text { OFC (olanzapine 6-12) vs. } \\
\text { Placebo }\end{array}$ & Change from baseline MADRS & $\begin{array}{l}\text { OFC }-18.5 \text { vs. Olanzapine }-15.0 \text { vs. } \\
\text { Placebo }-11.9 ; \text { OFC }>\text { placebo, } \\
\text { OFC > olanzapine }\end{array}$ & $\begin{array}{c}\text { OFC } 6.4 \% \text { vs. } \\
\text { Olanzapine } 5.7 \% \text { vs. } \\
\text { Placebo } 6.7 \% \\
\text { no significant difference }\end{array}$ \\
\hline $\begin{array}{l}\text { Sachs et al., } \\
2007[36]\end{array}$ & 366 (BP I \& II) & 26 & $\begin{array}{c}\text { Paroxetine } 20-40 \text { vs. } \\
\text { bupropion } 150-300 \text { vs. } \\
\text { Placebo; } \\
\text { add-on mood stabilizers }\end{array}$ & $\begin{array}{l}\text { Durable recovery : At least } \\
\text { eight consecutive weeks of } \\
\text { euthymia }\end{array}$ & $\begin{array}{l}\text { Antidepressants } 23 \% \text { vs. } \\
\quad \text { Placebo } 27.3 \% \text {; } \\
\text { no significant difference }\end{array}$ & $\begin{array}{l}\text { Antidepressants } 10.1 \% \text { vs. } \\
\quad \text { Placebo } 10.7 \%\end{array}$ \\
\hline
\end{tabular}


Table 1. Cont

\begin{tabular}{|c|c|c|c|c|c|c|}
\hline Study & $\begin{array}{l}\text { Number of Bipolar } \\
\text { Subjects (Type) }\end{array}$ & Duration (Weeks) & $\begin{array}{c}\text { Antidepressant vs. } \\
\text { Comparators (Doses, mg/d) }\end{array}$ & Primary Outcome Evaluation & Efficacy of Responders/Cases & Mood Switching \\
\hline $\begin{array}{l}\text { McElroy et al., } \\
2010[31]\end{array}$ & 740 (BP I \& II) & 8 & $\begin{array}{c}\text { Paroxetine } 20 \text { vs. } \\
\text { Quetiapine } 300 \text { or } 600 \text { vs. } \\
\text { Placebo }\end{array}$ & Change from baseline MADRS & $\begin{array}{c}\text { Paroxetine }-13.76 \text { vs. } \\
\text { Quetiapine } 300,-16.19 \text { vs. } \\
\text { Quetiapine } 600,-16.31 \text { vs. } \\
\quad \text { Placebo }-12.60 ; \\
\text { both quetiapine }>\text { placebo, } \\
\text { paroxetine }>\text { placebo }\end{array}$ & $\begin{array}{l}\text { Paroxetine } 10.7 \% \text { vs. } \\
\text { Quetiapine } 300,2.1 \% \text { vs. } \\
\text { Quetiapine } 600,4.1 \% \text { vs. } \\
\text { Placebo } 8.9 \%\end{array}$ \\
\hline $\begin{array}{l}\text { Altshuler et al., } \\
2017 \text { [45] }\end{array}$ & 142 (BP II) & 16 & $\begin{array}{c}\text { Sertraline }>100 \text { vs. } \\
\text { Lithium }>900 \text { vs. } \\
\text { Combination of both drugs }\end{array}$ & Switch to hypomania or mania & $\begin{array}{c}\text { Sertraline } 73.3 \% \text { vs. } \\
\text { Lithium } 67.4 \% \text { vs. } \\
\text { Combination of both drugs } 47.9 \% ; \\
\text { no significant difference }\end{array}$ & $\begin{array}{l}\text { Sertraline } 17.8 \% \text { vs. } \\
\text { Lithium } 14.3 \% \text { vs. } \\
\text { Combination of both } \\
\text { drugs } 10.4 \% \text {; } \\
\text { no significant difference }\end{array}$ \\
\hline \multicolumn{7}{|c|}{ SSRIs vs. other drugs } \\
\hline $\begin{array}{l}\text { Young et al., } \\
2000 \text { [46] }\end{array}$ & 27 (BP I \& II) & 6 & $\begin{array}{l}\text { Paroxetine } 36 \text { (mean) vs. } \\
\text { Lithium } 1300 \text { (mean) or } \\
\text { Divalproex } 1200 \text { (mean); } \\
\text { add-on lithium or divalproex }\end{array}$ & $\begin{array}{l}\text { Change from baseline HAMD, } \\
\text { YMRS, and GAF }\end{array}$ & $\begin{array}{c}\text { For HAMD, paroxetine }+ \text { lithium or } \\
\text { divalproex > lithium or divalproex; } \\
\text { for YMRS, no difference; for GAF, } \\
\text { paroxetine+lithium or divalproex > lithium } \\
\text { or divalproex }\end{array}$ & $\begin{array}{l}\text { Paroxetine was not } \\
\text { associated with the } \\
\text { emergence of } \\
\text { manic symptoms }\end{array}$ \\
\hline $\begin{array}{l}\text { Vieta et al., } \\
2002[47]\end{array}$ & 60 (BP I \& II) & 6 & $\begin{array}{l}\text { Paroxetine: } 20-60 \text { vs. } \\
\text { Venlafaxine: } 75-450\end{array}$ & Change from baseline HAMD & $\begin{array}{l}\text { Paroxetine: } 43 \% \text { vs. Venlafaxine: } 48 \% \text {; } \\
\text { venlafaxine > paroxetine }\end{array}$ & $\begin{array}{l}\text { Paroxetine } 3 \% \text { vs. } \\
\text { Venlafaxine } 13 \%\end{array}$ \\
\hline $\begin{array}{l}\text { Shelton et al., } \\
2004[48]\end{array}$ & 30 (BP I \& II) & 12 & $\begin{array}{l}\text { Paroxetine } 35.0 \pm 21.2 \text { vs., } \\
\text { Risperidone } 2.15 \pm 1.2 \text { vs. } \\
\text { Combination of both drugs; } \\
\text { add-on mood stabilizers }\end{array}$ & Change from baseline HAMD & $\begin{array}{c}\text { Paroxetine } 5.6 \pm 6.5 \mathrm{vs} . \\
\text { Risperidone } 5.2 \pm 8.7 \mathrm{vs} . \\
\text { Combination of both drugs } 6.3 \pm 6.5 ; \\
\text { no significant difference } \\
\end{array}$ & None \\
\hline $\begin{array}{l}\text { Post et al., } \\
2006[49]\end{array}$ & 184 (BP I \& II) & 10 & $\begin{array}{l}\text { Sertraline } 50-200 \text { vs. } \\
\text { Bupropion } 75-450 \text { vs. } \\
\text { Venlafaxine } 37.5-375 ; \\
\text { add-on mood stabilizers }\end{array}$ & $\begin{array}{l}\text { Response ( } \geq 50 \% \text { improvement } \\
\text { in IDS score or a decrease in } \\
\text { the CGI-BP depression score } \\
\text { of } \geq 2 \text { ) }\end{array}$ & $\begin{array}{l}\text { Bupropion } 49 \% \text { vs. } \\
\text { Sertraline } 53 \% \text { vs. } \\
\text { Venlafaxine } 51 \% \text {; } \\
\text { no significant difference }\end{array}$ & $\begin{array}{c}\text { Bupropion } 14 \% \text {, } \\
\text { Sertraline } 16 \% \\
\text { Venlafaxine } 31 \% \text {; } \\
\text { venlafaxine > bupropion } \\
\text { or sertraline }\end{array}$ \\
\hline $\begin{array}{l}\text { Schaffer et al., } \\
2006[50]\end{array}$ & 20 (BP I \& II) & 12 & $\begin{array}{l}\text { Ciralopram } 10-30 \text { vs. } \\
\text { Lamotrigine } 50-200 \\
\text { (no divalproex) and } 25-100 \\
\text { (with divalproex); } \\
\text { add-on mood stabilizers }\end{array}$ & Change from baseline MADRS & $\begin{array}{l}\text { Ciralopram }-14.2 \text { vs. } \\
\text { Lamotrigine - } 13.3 ; \\
\text { no significant difference }\end{array}$ & $\begin{array}{l}\text { Ciralopram } 1 \text { patient vs. } \\
\text { Lamotrigine } 1 \text { patients; } \\
\text { no significant difference }\end{array}$ \\
\hline $\begin{array}{l}\text { Brown et al., } \\
2006[35]\end{array}$ & 410 (BP I) & 7 & $\begin{array}{l}\text { Fluoxetine (OFC) } 25-50 \text { vs. } \\
\text { Lamotrigine } 200\end{array}$ & Change from baseline CGI-S & $\begin{array}{l}\text { Fluoxetine (OFC) }-1.43 \text { vs. } \\
\text { Lamotrigine }-1.18 \\
\text { OFC > lamotrigine }\end{array}$ & $\begin{array}{l}\text { Fluoxetine (OFC) } 4.0 \% \text { vs. } \\
\text { Lamotrigine } 5.2 \% \text {; } \\
\text { no significant difference }\end{array}$ \\
\hline
\end{tabular}


Table 1. Cont.

\begin{tabular}{|c|c|c|c|c|c|c|}
\hline Study & $\begin{array}{l}\text { Number of Bipolar } \\
\text { Subjects (Type) }\end{array}$ & Duration (Weeks) & $\begin{array}{c}\text { Antidepressant vs. } \\
\text { Comparators (Doses, mg/d) }\end{array}$ & Primary Outcome Evaluation & Efficacy of Responders/Cases & Mood Switching \\
\hline $\begin{array}{l}\text { Altshuler et al., } \\
\quad 2017 \text { [45] }\end{array}$ & 142 (BP II) & 16 & $\begin{array}{l}\text { Sertraline }>100 \text { vs. } \\
\text { Lithium }>900 \text { vs. } \\
\text { Combination of both drugs }\end{array}$ & Switch to hypomania or mania & $\begin{array}{c}\text { Sertraline } 73.3 \% \text { vs. } \\
\text { Lithium } 67.4 \% \text { vs. } \\
\text { Combination of both drugs } 47.9 \% ; \\
\text { no significant difference }\end{array}$ & $\begin{array}{c}\text { Sertraline } 17.8 \% \text { vs. } \\
\text { Lithium } 14.3 \% \text { vs. } \\
\text { Combination of both } \\
\text { drugs } 10.4 \% ; \\
\text { no significant difference }\end{array}$ \\
\hline \multicolumn{7}{|c|}{ SNRIs } \\
\hline $\begin{array}{l}\text { Amsterdam, } \\
1998 \text { [51] }\end{array}$ & 17 (BP II) & 6 & Venlafaxine $37.5-225$ & Change from baseline HAMD & $\begin{array}{c}\text { Venlafaxine } 10 \pm 8 \\
\text { no comparison within } \mathrm{BP} \\
\text { only BP vs. UP comparison }\end{array}$ & None \\
\hline $\begin{array}{l}\text { Amsterdam, } \\
2000[52]\end{array}$ & 15 (BP II) & 6 & Venlafaxine $37.5-225$ & $\begin{array}{l}\text { Response rate }(\geq 50 \% \text { reduction } \\
\text { from baseline HAMD) }\end{array}$ & $\begin{array}{c}\text { Venlafaxine } 63 \% \text {; no comparison within BP, } \\
\text { only BP vs. UP comparison }\end{array}$ & None \\
\hline $\begin{array}{l}\text { Amsterdam, } \\
2016[53]\end{array}$ & 129 (BP II) & 12 & $\begin{array}{l}\text { Venlafaxine } 37.5-75 \text { vs. } \\
\text { Lithium } 300-600 \mathrm{mg}\end{array}$ & $\begin{array}{c}\text { Response rate }(>50 \% \text { reduction } \\
\text { from baseline HAMD plus } \\
\text { final CGI-S) }\end{array}$ & $\begin{array}{l}\text { Venlafaxine } 67.7 \% \text { vs. Lithium } 34.4 \% \text {; } \\
\text { venlafaxine > lithium }\end{array}$ & None \\
\hline \multicolumn{7}{|c|}{ NDRIs } \\
\hline $\begin{array}{l}\text { Sachs et al., } \\
1994[54]\end{array}$ & 15 (BP I \& II) & 8 & $\begin{array}{l}\text { Bupropion } 358 \pm 62 \text { vs. } \\
\text { Desipramine } 140 \pm 46\end{array}$ & $\begin{array}{l}\text { Response rate ( }>50 \% \text { reduction } \\
\text { from baseline HAMD) }\end{array}$ & $\begin{array}{l}\text { Bupropion } 63 \% \text { vs. Desipramine } 71 \% \text {; } \\
\text { no significant difference }\end{array}$ & $\begin{array}{c}\text { Bupropion } 11 \% \text { vs. } \\
\text { Desipramine } 50 \% ; \\
\text { Desipramine > bupropion }\end{array}$ \\
\hline $\begin{array}{l}\text { Grossman et al., } \\
1999[55]\end{array}$ & 16 (BP I) & 6 & $\begin{array}{l}\text { Bupropion } 450 \text { vs. } \\
\text { Idazoxan } 240 ; \\
\text { add-on lithium }\end{array}$ & Change from baseline HAMD & $\begin{array}{l}\text { Bupropion }-1.54 \text { vs. Idazoxan }-1.06 \text {; } \\
\text { no significant difference }\end{array}$ & No mention \\
\hline \multicolumn{7}{|c|}{ Agomelatine } \\
\hline $\begin{array}{l}\text { Yatham et al., } \\
2016 \text { [37] }\end{array}$ & 344 (BP I) & 8 & $\begin{array}{l}\text { Agomelatine } 25-50 \text { vs. } \\
\text { Placebo; } \\
\text { add on lithium or valproate }\end{array}$ & Change from baseline MADRS & $\begin{array}{c}\text { Agomelatine }-15.4 \text { vs. Placebo }-15.2 ; \\
\text { no significant difference }\end{array}$ & $\begin{array}{l}\text { Agomelatine } 4.1 \% \text { vs. } \\
\quad \text { Placebo } 3.5 \%\end{array}$ \\
\hline
\end{tabular}

(Abbreviations: BDI, Beck Depression Inventory; HAMD, ; CGI-I, clinical global impression severity-improvement; MADRS, Montgomery-Asberg depression rating scale; OFC olanzapine-fluoxetine combination; IDS, Inventory of depressive symptomatology; CGI-BP, clinical global impression-bipolar version, YMRS, young mania rating scale; GAF, global assessment of functioning scale). 
Interestingly, the bupropion group showed a significantly lower risk of mood switch rates compared to other ADs (sertraline, venlafaxine, and desipramine); however, compared to other ADs, venlafaxine must be used cautiously $[47,49,56]$. Therefore, adjunctive treatments with SNRIs, such as venlafaxine or tricyclic antidepressants (TCAs), should be considered only after other ADs (e.g., bupropion, SSRIs) have been administered, and must be closely monitored due to an increased risk of mood switching and destabilization $[8,33,57]$.

There is a lack of data regarding rapid cycling of ADs in RCTs. As part of the Systematic Treatment Enhancement Program for Bipolar Disorder (STEP-BD) study, AD continuation with rapid cycling was associated with worsened maintenance outcomes, especially for depressive morbidity, compared to the AD discontinuation group [58]. However, rapid cycling status may not be associated with a diminished response or greater depressive relapse during venlafaxine treatment relative to lithium monotherapy in bipolar II subjects [59]. Additional research is required in this area.

There is still a lack of evidence that the use of ADs for depression in BDs increases suicidal ideation and suicidal behavior, AD monotherapy of bipolar depression may entrain a course characterized by higher proneness to mood switches and suicidal behavior [60,61]. However, in some studies, patients with bipolar I and II disorders showed either no evidence of, or a significant reduction in, the risk of suicidal behavior during periods of AD exposure [62-64]. It should be noted that some suicidal subjects had unconfirmed mixed features $[61,65,66]$.

\subsection{Clinical Application of ADs}

In clinical practice, most guidelines recommend combination therapy with MSs or AAPs, particularly lamotrigine and AAPs, rather than AD monotherapy for bipolar depression $[4,5,7,67,68]$. For mild to moderately severe cases, adjunctive AD therapy is often recommended as the second-line intervention, using SSRIs or bupropion combined with MSs or AAPs, particularly OFC. For moderate to severe cases, $\mathrm{AD}$ combination therapies are considered the first-line intervention.

Currently, there are no set guidelines for the dosage of ADs for bipolar depression. Tada et al. suggested that dose increments of adjunctive ADs might need to be considered for those receiving low doses who remain unresponsive [69]. Although there is a lack of evidence regarding the relationship between AD dose and mood switching in bipolar depression, use of adjunctive ADs may be associated with increased severity of manic symptoms in the STEP-BD [70].

\subsection{ADs for Maintenance}

Clinically, long-term AD use for depression in BD patients is very common. However, their role in preventing depressive or manic episode relapse is doubtful. There seems to be a prophylactic effect on depressive episodes. In a RCT of long-term fluoxetine versus lithium monotherapy for bipolar II disorder, fluoxetine monotherapy provided superior relapse prevention compared to lithium monotherapy as a maintenance treatment, although the results for fluoxetine and the placebo were comparable [71]. In a STEP-BD study of ADs' long-term effectiveness and safety, AD continuation with MSs trended toward less severe depressive symptoms (difference in DSM-IV depression criteria $=-1.84,95 \% \mathrm{CI}-0.08-3.77)$ and mildly delayed depressive episode relapse, without increased manic symptoms (mean difference in DSM-IV mania criteria $=+0.29,95 \% \mathrm{CI}-0.73-1.20$ ), although a rapid cycling course predicted three times more depressive episodes with AD continuation (rapid cycling $=1.29$, non-rapid cycling $=0.42$ episodes $/$ year, $p=0.04)$ [72].

However, in a meta-analysis of seven RCTs (350 bipolar depression patients), long-term treatment with MSs in combination with ADs yielded neither major protection from depression $(R R=0.84$, $95 \%$ CI $0.56-1.27)$ nor a substantial increase in the risk of mania ( $R R=1.37,95 \%$ CI $0.81-2.33)$ [9]. In a study of venlafaxine continuation, there were no differences in relapse rates between venlafaxine and lithium $(7.5 \%$ vs. $26.7 \%, p=0.079)$, relapse hazard $(p=0.073)$, or time to relapse $(p=0.090)$, possibly due to the small sample size and lack of a placebo [29]. 
In conclusion, the efficacy of AD monotherapy in maintenance and in preventing recurrence are inconclusive. However, long-term AD use with anti-manic drugs in BDs may not increase the risk of relapse of mood disorder.

\section{MSs}

\subsection{Lithium}

In the clinical literature on the acute depressive phase of BDs, eight of nine controlled comparisons found lithium superior to the placebo in depressed bipolar patients [73]. For prophylactic treatment, the usefulness of lithium against bipolar depression was confirmed together with its specific effectiveness for suicide prevention [74]. These anti-suicidal effects are possibly due to reducing mood disorder relapse, but additional mechanisms must be considered since there is some evidence that lithium decreases aggression and, possibly, impulsivity [75]. However, some studies indicate that lithium may be less effective for depression than lamotrigine; lamotrigine may provide a spectrum of efficacy complementary to that of lithium [76,77].

Table 1 shows that AD adjunctive therapy in addition to lithium may be beneficial. This is particularly observed in patients who cannot tolerate high serum lithium levels or those who have symptoms that are refractory to the AD effects of lithium [44]. Among patients with delayed onset of therapeutic response and a high number of non-responders to ADs, there is firm evidence for lithium as an effective augmentation strategy, but only modest evidence that lithium accelerates the response to ADs in patients with depression [78].

From the viewpoint that the concept of disease gradually expands into the bipolar-spectrum, longitudinal follow-up found a positive response to lithium augmentation in treatment-resistant MDE-related bipolar-spectrum disorder [79]. This maintenance treatment, lithium monotherapy, was associated with a significantly reduced risk of both manic/mixed and depressed relapse [74]. Moreover, quetiapine combination significantly reduced the risk of relapse of manic/mixed and depressive episodes in bipolar illness compared to the placebo. The risk of early recurrence of BDs, especially of mania, was found to increase following discontinuation of lithium use and may exceed that predicted in the course of the untreated disorder [80].

Lithium is an essential form of treatment but must not be applied monotherapeutically for bipolar depression, particularly in the treatment of severe bipolar depression [81]. As a combination treatment, lithium effectively prevents relapse and is particularly useful in patients with a high risk of suicide.

\subsection{Lamotrigine}

There have been several long-term studies of the effects of lamotrigine in the treatment of bipolar depression. Two placebo-controlled 18-month trials of lamotrigine indicated that it was effective against depression and mania, with more robust activity against depression [77]. In a long-term study involving 124 patients with bipolar depression receiving lithium, addition of lamotrigine was significantly more effective than the placebo during the acute phase, and continued to be beneficial compared to the placebo during the maintenance phase [82]. However, the effects of lamotrigine on the acute phase of bipolar depression are diverse and need to be studied further. In a naturalistic, open-label study of patients with bipolar II disorder, treatment of acute depression with lamotrigine or lithium showed comparable response and remission rates [83]. Another RCT did not demonstrate efficacy of lamotrigine monotherapy as an acute treatment, although it was well tolerated [84]. A RCT of the acute phase, comparing OFC to lamotrigine, showed that OFC-treated patients showed significant improvement compared to lamotrigine-treated patients in Clinical Global Impression-Improvement (CGI-I) response and time to response, although the OFC treatment had undesirable side effects such as greater weight gain and some elevated metabolic factors compared to lamotrigine [35]. Most guidelines recommend lamotrigine as the first-line treatment for mild to moderate bipolar 
depression $[4,5,7,67,68,85]$. Additionally, lamotrigine monotherapy or combined with lithium or AAPs is generally recommended.

For maintenance treatment, it has been reported that lamotrigine is effective in the prevention of depression, particularly the combination of lithium and lamotrigine [86]. However, the overall pool effect was only modest, although the advantage over the placebo was larger in more severely depressed patients [87].

\subsection{Valproate/Carbamazepine}

There have been several meta-studies related to treatment of the acute phase of bipolar depression with valproate and carbamazepine. One study on valproate showed that patients' responses to, and remission with, valproate were significantly greater than with the placebo [88]. According to another study, valproate and carbamazepine also produced favorable response rates compared to the placebo group, and the number needed to treat (NNT) was also low (valproate 4.4 and carbamazepine 3.4) [89]. However, because the sample size of both studies was small ( $N=140$ and $N=142$, respectively), more research is needed to make a definitive conclusion.

For maintenance treatment, some research suggests that valproate may prevent depressive episodes. Valproate and carbamazepine may be effective for bipolar depression, leading to decreased worsening of depressive symptoms and a reduced probability of depressive relapse [74,90]. A pilot study reported that a combination of lithium and valproate significantly reduced the chances of relapse or recurrence, although it was more likely to cause moderate to severe adverse side effects [91]. A small RCT of carbamazepine concluded that it was as effective as lithium in the prophylaxis of bipolar affective disorder [92]. However, some studies have shown that the prophylactic effect of carbamazepine is relatively low compared to other MSs or lithium, and that it may be better for broader spectrum disorders, such as bipolar II or bipolar not otherwise specified rather than lithium [93-96]. Additionally, lithium combination treatment, rather than carbamazepine monotherapy, has been shown to help prevent new episodes of relapse [97].

In conclusion, there is little evidence for the efficacy of valproate or carbamazepine for acute bipolar depression, even though they are the most frequently prescribed MSs for BDs. To date, valproate and carbamazepine have been found to be less effective during acute-phase treatment of bipolar depression, maintenance treatment, and for depression relapse prevention compared to other MSs and lithium [98].

\section{Novel Research Avenues}

To date, there are no significant biomarkers for mood disorders. The role of clinical evaluation in distinguishing between MDDs and BDs is very important. As shown in the differential diagnosis process in Figure 1, the history of hypomanic symptoms and long-term follow-up are the most obvious ways to distinguish bipolarity. Thus, most patients with MDEs undergo early AD monotherapy. In the process of clinical examination and observation of pharmacological responses, if bipolarity or mixed features are suspected, or if there is a partial or no response to early AD monotherapy, the classes of ADs are appropriately modified and combined with lithium and MSs or AAPs. However, the trial and error process of psychiatric treatment can worsen symptoms such as mood switching and rapid cycling, and lead to suicidal behavior. Therefore, it is necessary to develop biomarkers that can distinguish between mood disorders biologically before initiating treatment. This requires an understanding of the pathophysiology associated with MDDs and BDs.

Recent findings suggest that molecular biology, genetic/epigenetic markers, neuroimaging, and inflammatory markers, oxidative stress, and mitochondrial dysfunction may be candidates to provide differential diagnosis and indicate drug responsiveness. The relationship of single nucleotide polymorphism (SNP) to AD responsiveness has been determined. Recently, gene-expression analysis has examined the involvement of miRNA in predisposing biological processes associated with antidepressant responses. miRNA in peripheral blood leukocytes may be a biomarker for MDDs, 
suicide, and cognitive function [99-101]. If genetic studies can predict a patient's drug responsiveness, then the most appropriate drug can be selected as personalized medicine. In the case of mental illness, there are too many complex considerations involving social and psychological factors, and research on genetic pathophysiology has been lacking. However, in the case of other diseases, biological studies on pathophysiology and drug responses have been actively conducted and are already in the process of providing personalized drug treatments. Mood disorders, particularly MDEs, which are among the most common diseases in psychiatry will follow this trend.

For example, differences in fluoxetine response may be due to the influence of certain genes involved in fluoxetine transportation. Genetic variation in transport and remission, recovery, suicide risk, and other factors such as stress, family support, and other genetic factors are likely to be involved in MDD outcomes [102]. In addition, if venlafaxine is more effective in Val/Val patients than Met/Met carriers, the Catechol-O-methytransferase (COMT) Val/Met genetic polymorphism can be recommended as a biomarker for the prediction of venlafaxine efficacy in patients treated in psychiatric settings [103]. For MSs, evidence increasingly suggests that genetic factors play a strong role in the variation of response to lithium, and development of a method to predict individual responses to lithium could thereby accelerate recovery and reduce suffering and cost [104].

Neuroimaging, such as functional functional magnetic resonance imaging (fMRI) and positron emission tomography (PET), may reveal different responses in patients who respond well to a particular AD class or MS class, compared to those who do not respond. In PET of patients with unipolar depression, rostral anterior cingulate metabolism uniquely differentiated eventual treatment responders (hypermetabolism) from non-responders (hypometabolism) [105]. Increased glucose metabolism in cortico-limbic circuitry revealed by PET was related to successful paroxetine treatment response [106]. A recent fMRI study had better prognostic value than current practice based on clinical impressions $[107,108]$. Although various studies have examined the relationship between immune status, including various C-reactive protein or pro-inflammatory cytokines, and AD responsiveness, the results have been inconsistent. Peripheral blood inflammatory biomarkers may contribute to personalized treatment choice and improved AD outcomes [109].

The effects of oxidative stress on mood disorders are shown to result in a down-regulation of anti-oxidant reactions in the hippocampus, such as superoxide dismutase, catalase, glutathione peroxidase, glutathione-S-transferase, and other genes $[110,111]$. Accumulation of oxidative damage to mitochondria in brain might lead neuronal cellular death as a result of aggregation of oxidized protein, which may result in neurodegeneration [112]. In conclusion, to anticipate diagnostic differentiation of psychiatric illnesses and individual responses to classes of medication, and to realize personalized medicine, an understanding of the pathophysiology of depression and the development of simple and accessible biomarkers are required. To date, research on various basic sciences, such as genetic/epigenetic, proteomic, neuroimaging, and inflammatory factors, has been underway, and some candidate approaches have been suggested. However, no definite biomarker has yet been found and further studies are needed.

\section{Conclusions}

Historically, bisection of mood disorders into MDDs and BDs has been relatively rapid. Additionally, the concept of bipolar spectrum and the proportion of shared features between MDDs and BDs has led to increasingly divergent diagnoses. Under these circumstances, cautious pharmacological treatment must be administered using ADs and MSs in MDEs and for long-term stability of BDs. For initial treatment of MDEs, screening tools (e.g., HCL-32, MDQ, SAD-P, YMRS), specific symptom evaluation through mental status examination, and careful history taking should be performed to distinguish bipolarity from mixed features for which AD monotherapy may represent a risk. Depending on the therapeutic response, the existing guidelines and the results of empirical research findings can be followed. Currently, AD monotherapy should be avoided in patients strongly suspected as having bipolar depression or MDDs with mixed features. In these patients, a combination or 
adjunctive treatment with MSs or AAPs is recommended when it is considered beneficial to use ADs. MS efficacy studies on bipolar depression suggest that lamotrigine is the most reliable; lithium is expected to have modest effects, and evidence is still lacking regarding the efficacy of valproate and carbamazepine. To prevent long-term episodic relapse in BDs, MSs may also be recommended, either alone or in combination with other MSs and AAPs. Despite these therapeutic efforts, mood disorders are chronic psychiatric illnesses that are frequently recurrent and difficult to treat. There is a continuing need for novel research and further development of these drugs. Recently, radical progress has been achieved in research into pathophysiology and biomarkers in the fields of molecular biology, genetic/epigenetics, and neuroimaging. There is also an opportunity to study novel drug mechanisms through the rediscovery of fast-acting drugs, including ketamine. Through this process, it is anticipated that research will develop in the direction of discovering potential targets for new drugs and applying them to personalized treatments.

Author Contributions: Authors In Hee Shim and Won-Myong Bahk designed the study and wrote the protocol; authors In Hee Shim, Young Sup Woo, Moon-Doo Kim, and Won-Myong Bahk managed the literature searches, summaries of previous related work; all authors participated in the collection of data, and the order of authors was determined according to their contribution; author In Hee Shim wrote the first draft of the manuscript; all authors contributed to and have approved the final manuscript.

Conflicts of Interest: The authors declare no conflict of interest.

\section{References}

1. ReferencesKennedy, S.H.; Lam, R.W.; McIntyre, R.S.; Tourjman, S.V.; Bhat, V.; Blier, P.; Hasnain, M.; Jollant, F.; Levitt, A.J.; MacQueen, G.M.; et al. Canadian Network for Mood and Anxiety Treatments (CANMAT) 2016 Clinical Guidelines for the Management of Adults with Major Depressive Disorder: Section 3. Pharmacological Treatments. Can. J. Psychiatry 2016, 61, 540-560.

2. Malhi, G.S.; Bassett, D.; Boyce, P.; Bryant, R.; Fitzgerald, P.B.; Fritz, K.; Hopwood, M.; Lyndon, B.; Mulder, R.; Murray, G. Royal Australian and New Zealand College of Psychiatrists clinical practice guidelines for mood disorders. Aust. N. Z. J. Psychiatry 2015, 49, 1087-1206. [CrossRef] [PubMed]

3. Bauer, M.; Pfennig, A.; Severus, E.; Whybrow, P.C.; Angst, J.; Moller, H.J. World Federation of Societies of Biological Psychiatry (WFSBP) guidelines for biological treatment of unipolar depressive disorders, part 1: Update 2013 on the acute and continuation treatment of unipolar depressive disorders. World J. Biol. Psychiatry 2013, 14, 334-385. [CrossRef] [PubMed]

4. Woo, Y.S.; Lee, J.G.; Jeong, J.-H.; Kim, M.-D.; Sohn, I.; Shim, S.-H.; Jon, D.-I.; Seo, J.S.; Shin, Y.-C.; Min, K.J. Korean medication algorithm project for bipolar disorder: Third revision. Neuropsychiatr. Dis. Treat. 2015, 11, 493. [PubMed]

5. Yatham, L.N.; Kennedy, S.H.; Parikh, S.V.; Schaffer, A.; Beaulieu, S.; Alda, M.; O'Donovan, C.; MacQueen, G.; McIntyre, R.S.; Sharma, V. Canadian Network for Mood and Anxiety Treatments (CANMAT) and International Society for Bipolar Disorders (ISBD) collaborative update of CANMAT guidelines for the management of patients with bipolar disorder: Update 2013. Bipolar Disord. 2013, 15, 1-44. [CrossRef] [PubMed]

6. Grunze, H.; Vieta, E.; Goodwin, G.M.; Bowden, C.; Licht, R.W.; Möller, H.-J.; Kasper, S.; Grunze, H.; Vieta, E. The World Federation of Societies of Biological Psychiatry (WFSBP) guidelines for the biological treatment of bipolar disorders: Update 2009 on the treatment of acute mania. World J. Biol. Psychiatry 2009, 10, 85-116. [CrossRef] [PubMed]

7. Grunze, H.; Vieta, E.; Goodwin, G.M.; Bowden, C.; Licht, R.W.; Möller, H.-J.; Kasper, S. The World Federation of Societies of Biological Psychiatry (WFSBP) guidelines for the biological treatment of bipolar disorders: Update 2012 on the long-term treatment of bipolar disorder. World J. Biol. Psychiatry 2013, 14, 154-219. [CrossRef] [PubMed]

8. Pacchiarotti, I.; Bond, D.J.; Baldessarini, R.J.; Nolen, W.A.; Grunze, H.; Licht, R.W.; Post, R.M.; Berk, M.; Goodwin, G.M.; Sachs, G.S.; et al. The International Society for Bipolar Disorders (ISBD) task force report on antidepressant use in bipolar disorders. Am. J. Psychiatry 2013, 170, 1249-1262. [CrossRef] [PubMed] 
9. Ghaemi, S.N.; Wingo, A.P.; Filkowski, M.A.; Baldessarini, R.J. Long-term antidepressant treatment in bipolar disorder: Meta-analyses of benefits and risks. Acta Psychiatr. Scand. 2008, 118, 347-356. [CrossRef] [PubMed]

10. Lish, J.D.; Dime-Meenan, S.; Whybrow, P.C.; Price, R.A.; Hirschfeld, R.M. The National Depressive and Manic-depressive Association (DMDA) survey of bipolar members. J. Affect. Disord. 1994, 31, 281-294. [CrossRef]

11. Hirschfeld, R.M.; Lewis, L.; Vornik, L.A. Perceptions and impact of bipolar disorder: How far have we really come? Results of the national depressive and manic-depressive association 2000 survey of individuals with bipolar disorder. J. Clin. Psychiatry 2003, 64, 161-174. [CrossRef] [PubMed]

12. Morselli, P.L.; Elgie, R. GAMIAN-Europe/BEAM survey I-Global analysis of a patient questionnaire circulated to 3450 members of 12 European advocacy groups operating in the field of mood disorders. Bipolar Disord. 2003, 5, 265-278. [CrossRef] [PubMed]

13. Ghaemi, S.N.; Sachs, G.S.; Chiou, A.M.; Pandurangi, A.K.; Goodwin, K. Is bipolar disorder still underdiagnosed? Are antidepressants overutilized? J. Affect. Disord. 1999, 52, 135-144. [CrossRef]

14. Cuellar, A.K.; Johnson, S.L.; Winters, R. Distinctions between bipolar and unipolar depression. Clin. Psychol. Rev. 2005, 25, 307-339. [CrossRef] [PubMed]

15. Mitchell, P.B.; Goodwin, G.M.; Johnson, G.F.; Hirschfeld, R. Diagnostic guidelines for bipolar depression: A probabilistic approach. Bipolar Disord. 2008, 10, 144-152. [CrossRef] [PubMed]

16. Pini, S.; de Queiroz, V.; Pagnin, D.; Pezawas, L.; Angst, J.; Cassano, G.B.; Wittchen, H.-U. Prevalence and burden of bipolar disorders in European countries. Eur. Neuropsychopharmacol. 2005, 15, 425-434. [CrossRef] [PubMed]

17. Perlis, R.H.; Brown, E.; Baker, R.W.; Nierenberg, A.A. Clinical features of bipolar depression versus major depressive disorder in large multicenter trials. Am. J. Psychiatry 2006, 163, 225-231. [CrossRef] [PubMed]

18. Forty, L.; Jones, L.; Jones, I.; Smith, D.J.; Caesar, S.; Fraser, C.; Gordon-Smith, K.; Hyde, S.; Craddock, N. Polarity at illness onset in bipolar I disorder and clinical course of illness. Bipolar Disord. 2009, 11, 82-88. [CrossRef] [PubMed]

19. Winokur, G.; Coryell, W.; Keller, M.; Endicott, J.; Leon, A. A family study of manic-depressive (bipolar I) disease: Is it a distinct illness separable from primary unipolar depression? Arch. Gen. Psychiatry 1995, 52, 367-373. [CrossRef] [PubMed]

20. Cassidy, F.; Ahearn, E.P.; Carroll, B.J. Substance abuse in bipolar disorder. Bipolar Disord. 2001, 3, $181-188$. [CrossRef] [PubMed]

21. Kelly, E.; Sharma, V. Diagnosis and treatment of postpartum bipolar depression. Expert Rev. Neurother. 2010, 10, 1045-1051. [CrossRef] [PubMed]

22. Reinares, M.; Vieta, E. Course and outcome patterns of depression: From unipolar episode to bipolar disorder. Medicographia 2011, 33, 145-150.

23. Tohen, M.; Zarate, C.A., Jr.; Hennen, J.; Khalsa, H.M.; Strakowski, S.M.; Gebre-Medhin, P.; Salvatore, P.; Baldessarini, R.J. The McLean-Harvard First-Episode Mania Study: Prediction of recovery and first recurrence. Am. J. Psychiatry 2003, 160, 2099-2107. [CrossRef] [PubMed]

24. National Collaborating Centre for Mental Health. National Collaborating Centre for Mental Health. National Institute for Health and Clinical Excellence: Guidance. In Depression: The Treatment and Management of Depression in Adults (Updated Edition); The British Psychological Society \& The Royal College of Psychiatrists: Leicester, UK, 2010.

25. Wang, H.R.; Bahk, W.M.; Seo, J.S.; Woo, Y.S.; Park, Y.M.; Jeong, J.H.; Kim, W.; Shim, S.H.; Lee, J.G.; Jon, D.I.; et al. Korean medication algorithm for depressive disorder: Comparisons with other treatment guidelines. Clin. Psychopharmacol. Neurosci. 2017, 15, 199-209. [CrossRef] [PubMed]

26. Baldessarini, R.J.; Leahy, L.; Arcona, S.; Gause, D.; Zhang, W.; Hennen, J. Patterns of psychotropic drug prescription for U.S. patients with diagnoses of bipolar disorders. Psychiatr. Serv. 2007, 58, 85-91. [CrossRef] [PubMed]

27. Greil, W.; Haberle, A.; Haueis, P.; Grohmann, R.; Russmann, S. Pharmacotherapeutic trends in 2231 psychiatric inpatients with bipolar depression from the International AMSP Project between 1994 and 2009. J. Affect. Disord. 2012, 136, 534-542. [CrossRef] [PubMed]

28. Amsterdam, J.D.; Shults, J. Comparison of fluoxetine, olanzapine, and combined fluoxetine plus olanzapine initial therapy of bipolar type I and type II major depression-lack of manic induction. J. Affect. Disord. 2005, 87, 121-130. [CrossRef] [PubMed] 
29. Amsterdam, J.D.; Lorenzo-Luaces, L.; Soeller, I.; Li, S.Q.; Mao, J.J.; DeRubeis, R.J. Safety and effectiveness of continuation antidepressant versus mood stabilizer monotherapy for relapse-prevention of bipolar II depression: A randomized, double-blind, parallel-group, prospective study. J. Affect. Disord. 2015, 185, 31-37. [CrossRef] [PubMed]

30. Amsterdam, J.D.; Shults, J. Comparison of short-term venlafaxine versus lithium monotherapy for bipolar II major depressive episode: A randomized open-label study. J. Clin. Psychopharmacol. 2008, 28, 171-181. [CrossRef] [PubMed]

31. McElroy, S.L.; Weisler, R.H.; Chang, W.; Olausson, B.; Paulsson, B.; Brecher, M.; Agambaram, V.; Merideth, C.; Nordenhem, A.; Young, A.H. A double-blind, placebo-controlled study of quetiapine and paroxetine as monotherapy in adults with bipolar depression (EMBOLDEN II). J. Clin. Psychiatry 2010, 71, 163-174. [CrossRef] [PubMed]

32. Vazquez, G.H.; Tondo, L.; Undurraga, J.; Baldessarini, R.J. Overview of antidepressant treatment of bipolar depression. Int. J. Neuropsychopharmacol. 2013, 16, 1673-1685. [CrossRef] [PubMed]

33. Sidor, M.M.; Macqueen, G.M. Antidepressants for the acute treatment of bipolar depression: A systematic review and meta-analysis. J. Clin. Psychiatry 2011, 72, 156-167. [CrossRef] [PubMed]

34. Tohen, M.; Vieta, E.; Calabrese, J.; Ketter, T.A.; Sachs, G.; Bowden, C.; Mitchell, P.B.; Centorrino, F.; Risser, R.; Baker, R.W.; et al. Efficacy of olanzapine and olanzapine-fluoxetine combination in the treatment of bipolar I depression. Arch. Gen. Psychiatry 2003, 60, 1079-1088. [CrossRef] [PubMed]

35. Brown, E.B.; McElroy, S.L.; Keck, P.E., Jr.; Deldar, A.; Adams, D.H.; Tohen, M.; Williamson, D.J. A 7-week, randomized, double-blind trial of olanzapine/fluoxetine combination versus lamotrigine in the treatment of bipolar I depression. J. Clin. Psychiatry 2006, 67, 1025-1033. [CrossRef] [PubMed]

36. Sachs, G.S.; Nierenberg, A.A.; Calabrese, J.R.; Marangell, L.B.; Wisniewski, S.R.; Gyulai, L.; Friedman, E.S.; Bowden, C.L.; Fossey, M.D.; Ostacher, M.J.; et al. Effectiveness of adjunctive antidepressant treatment for bipolar depression. N. Engl. J. Med. 2007, 356, 1711-1722. [PubMed]

37. Yatham, L.N.; Vieta, E.; Goodwin, G.M.; Bourin, M.; de Bodinat, C.; Laredo, J.; Calabrese, J. Agomelatine or placebo as adjunctive therapy to a mood stabiliser in bipolar I depression: Randomised double-blind placebo-controlled trial. Br. J. Psychiatry 2016, 208, 78-86. [CrossRef] [PubMed]

38. Bocchetta, A.; Bernardi, F.; Burrai, C.; Pedditzi, M.; del Zompo, M. A double-blind study of L-sulpiride versus amitriptyline in lithium-maintained bipolar depressives. Acta Psychiatr. Scand. 1993, 88, 434-439. [CrossRef] [PubMed]

39. Agosti, V.; Stewart, J.W. Efficacy and safety of antidepressant monotherapy in the treatment of bipolar-II depression. Int. Clin. Psychopharmacol. 2007, 22, 309-311. [CrossRef] [PubMed]

40. Himmelhoch, J.M.; Thase, M.E.; Mallinger, A.G.; Houck, P. Tranylcypromine versus imipramine in anergic bipolar depression. Am. J. Psychiatry 1991, 148, 910-916. [PubMed]

41. Thase, M.E.; Mallinger, A.G. Treatment of imipramine-resistant recurrent depression, IV: A double-blind crossover study of tranylcypromine for anergic bipolar depression. Am. J. Psychiatry 1992, 149, 195. [PubMed]

42. Silverstone, T. Moclobemide vs. imipramine in bipolar depression: A multicentre double-blind clinical trial. Acta Psychiatr. Scand. 2001, 104, 104-109. [CrossRef] [PubMed]

43. Cohn, J.B.; Collins, G.; Ashbrook, E.; Wernicke, J.F. A comparison of fluoxetine imipramine and placebo in patients with bipolar depressive disorder. Int. Clin. Psychopharmacol. 1989, 4, 313-322. [CrossRef] [PubMed]

44. Nemeroff, C.B.; Evans, D.L.; Gyulai, L.; Sachs, G.S.; Bowden, C.L.; Gergel, I.P.; Oakes, R.; Pitts, C.D. Double-blind, placebo-controlled comparison of imipramine and paroxetine in the treatment of bipolar depression. Am. J. Psychiatry 2001, 158, 906-912. [CrossRef] [PubMed]

45. Altshuler, L.L.; Sugar, C.A.; McElroy, S.L.; Calimlim, B.; Gitlin, M.; Keck, P.E., Jr.; Aquino-Elias, A.; Martens, B.E.; Fischer, E.G.; English, T.L.; et al. Switch rates during acute treatment for bipolar ii depression with lithium, sertraline, or the two combined: A randomized double-blind comparison. Am. J. Psychiatry 2017, 174, 266-276. [CrossRef] [PubMed]

46. Young, L.T.; Joffe, R.T.; Robb, J.C.; MacQueen, G.M.; Marriott, M.; Patelis-Siotis, I. Double-blind comparison of addition of a second mood stabilizer versus an antidepressant to an initial mood stabilizer for treatment of patients with bipolar depression. Am. J. Psychiatry 2000, 157, 124-126. [CrossRef] [PubMed]

47. Vieta, E.; Martinez-Aran, A.; Goikolea, J.M.; Torrent, C.; Colom, F.; Benabarre, A.; Reinares, M. A randomized trial comparing paroxetine and venlafaxine in the treatment of bipolar depressed patients taking mood stabilizers. J. Clin. Psychiatry 2002, 63, 508-512. [CrossRef] [PubMed] 
48. Shelton, R.C.; Stahl, S.M. Risperidone and paroxetine given singly and in combination for bipolar depression. J. Clin. Psychiatry 2004, 65, 1715-1719. [CrossRef] [PubMed]

49. Post, R.M.; Altshuler, L.L.; Leverich, G.S.; Frye, M.A.; Nolen, W.A.; Kupka, R.W.; Suppes, T.; McElroy, S.; Keck, P.E.; Denicoff, K.D.; et al. Mood switch in bipolar depression: Comparison of adjunctive venlafaxine, bupropion and sertraline. Br. J. Psychiatry 2006, 189, 124-131. [CrossRef] [PubMed]

50. Schaffer, A.; Zuker, P.; Levitt, A. Randomized, double-blind pilot trial comparing lamotrigine versus citalopram for the treatment of bipolar depression. J. Affect. Disord. 2006, 96, 95-99. [CrossRef] [PubMed]

51. Amsterdam, J. Efficacy and safety of venlafaxine in the treatment of bipolar II major depressive episode. J. Clin. Psychopharmacol. 1998, 18, 414-417. [CrossRef] [PubMed]

52. Amsterdam, J.D.; Garcia-Espana, F. Venlafaxine monotherapy in women with bipolar II and unipolar major depression. J. Affect. Disord. 2000, 59, 225-229. [CrossRef]

53. Amsterdam, J.D.; Lorenzo-Luaces, L.; Soeller, I.; Li, S.Q.; Mao, J.J.; DeRubeis, R.J. Short-term venlafaxine v. lithium monotherapy for bipolar type II major depressive episodes: Effectiveness and mood conversion rate. Br. J. Psychiatry 2016, 208, 359-365. [CrossRef] [PubMed]

54. Sachs, G.S.; Lafer, B.; Stoll, A.L.; Banov, M.; Thibault, A.B.; Tohen, M.; Rosenbaum, J.F. A double-blind trial of bupropion versus desipramine for bipolar depression. J. Clin. Psychiatry 1994, 55, 391-393. [PubMed]

55. Grossman, F.; Potter, W.Z.; Brown, E.A.; Maislin, G. A double-blind study comparing idazoxan and bupropion in bipolar depressed patients. J. Affect. Disord. 1999, 56, 237-243. [CrossRef]

56. Gijsman, H.J.; Geddes, J.R.; Rendell, J.M.; Nolen, W.A.; Goodwin, G.M. Antidepressants for bipolar depression: A systematic review of randomized, controlled trials. Am. J. Psychiatry 2004, 161, 1537-1547. [CrossRef] [PubMed]

57. Salvi, V.; Fagiolini, A.; Swartz, H.A.; Maina, G.; Frank, E. The use of antidepressants in bipolar disorder. J. Clin. Psychiatry 2008, 69, 1307-1318. [CrossRef] [PubMed]

58. Ghaemi, S.N. Treatment of rapid-cycling bipolar disorder: Are antidepressants mood destabilizers? Am. J. Psychiatry 2008, 165, 300-302. [CrossRef] [PubMed]

59. Lorenzo-Luaces, L.; Amsterdam, J.D.; Soeller, I.; DeRubeis, R.J. Rapid versus non-rapid cycling bipolar II depression: Response to venlafaxine and lithium and hypomanic risk. Acta Psychiatr. Scand. 2016, 133, 459-469. [CrossRef] [PubMed]

60. Pacchiarotti, I.; Valentí, M.; Colom, F.; Rosa, A.R.; Nivoli, A.M.; Murru, A.; Sánchez-Moreno, J.; Vieta, E. Differential outcome of bipolar patients receiving antidepressant monotherapy versus combination with an antimanic drug. J. Affect. Disord. 2011, 129, 321-326. [CrossRef] [PubMed]

61. Undurraga, J.; Baldessarini, R.J.; Valenti, M.; Pacchiarotti, I.; Vieta, E. Suicidal risk factors in bipolar I and II disorder patients. J. Clin. Psychiatry 2012, 73, 778-782. [CrossRef] [PubMed]

62. Leon, A.C.; Fiedorowicz, J.G.; Solomonon, D.A.; Li, C.; Coryell, W.H.; Endicott, J.; Fawcett, J.; Keller, M.B. Risk of suicidal behavior with antidepressants in bipolar and unipolar disorders. J. Clin. Psychiatry 2014, 75, 720. [CrossRef] [PubMed]

63. Bauer, M.S.; Wisniewski, S.R.; Marangell, L.B.; Chessick, C.A.; Allen, M.H.; Dennehy, E.B.; Miklowitz, D.J.; Thase, M.E.; Sachs, G.S. Are antidepressants associated with new-onset suicidality in bipolar disorder? A prospective study of participants in the Systematic Treatment Enhancement Program for Bipolar Disorder (STEP-BD). J. Clin. Psychiatry 2006, 67, 48-55. [CrossRef] [PubMed]

64. Tondo, L.; Lepri, B.; Baldessarini, R.J. Suicidal status during antidepressant treatment in 789 Sardinian patients with major affective disorder. Acta Psychiatr. Scand. 2008, 118, 106-115. [CrossRef] [PubMed]

65. Koukopoulos, A.; Sani, G.; Koukopoulos, A.E.; Manfredi, G.; Pacchiarotti, I.; Girardi, P. Melancholia agitata and mixed depression. Acta Psychiatr. Scand. 2007, 115, 50-57. [CrossRef] [PubMed]

66. Rihmer, Z.; Gonda, X. Antidepressant-resistant depression and antidepressant-associated suicidal behaviour: The role of underlying bipolarity. Depress. Res. Treat. 2011, 2011, 906462. [CrossRef] [PubMed]

67. Goodwin, G.M. Consensus Group of the British Association for Psychopharmacology. Evidence-based guidelines for treating bipolar disorder: Revised second edition-recommendations from the British Association for Psychopharmacology. J. Psychopharmacol. 2009, 23, 346-388. [CrossRef] [PubMed]

68. National Collaborating Centre for Mental Health. Bipolar Disorder: The Assessment and Management of Bipolar Disorder in Adults, Children and Young People in Primary and Secondary Care; The British Psychological Society \& The Royal College of Psychiatrists: Leicester, UK, 2014. 
69. Tada, M.; Uchida, H.; Mizushima, J.; Suzuki, T.; Mimura, M.; Nio, S. Antidepressant dose and treatment response in bipolar depression: Reanalysis of the Systematic Treatment Enhancement Program for Bipolar Disorder (STEP-BD) data. J. Psychiatr. Res. 2015, 68, 151-156. [CrossRef] [PubMed]

70. Goldberg, J.F.; Perlis, R.H.; Ghaemi, S.N.; Calabrese, J.R.; Bowden, C.L.; Wisniewski, S.; Miklowitz, D.J.; Sachs, G.S.; Thase, M.E. Adjunctive antidepressant use and symptomatic recovery among bipolar depressed patients with concomitant manic symptoms: Findings from the STEP-BD. Am. J. Psychiatry 2007, 164, 1348-1355. [CrossRef] [PubMed]

71. Amsterdam, J.D.; Shults, J. Efficacy and safety of long-term fluoxetine versus lithium monotherapy of bipolar II disorder: A randomized, double-blind, placebo-substitution study. Am. J. Psychiatry 2010, 167, 792-800. [CrossRef] [PubMed]

72. Ghaemi, S.N.; Ostacher, M.M.; El-Mallakh, R.S.; Borrelli, D.; Baldassano, C.F.; Kelley, M.E.; Filkowski, M.M.; Hennen, J.; Sachs, G.S.; Goodwin, F.K.; et al. Antidepressant discontinuation in bipolar depression: A Systematic Treatment Enhancement Program for Bipolar Disorder (STEP-BD) randomized clinical trial of long-term effectiveness and safety. J. Clin. Psychiatry 2010, 71, 372-380. [CrossRef] [PubMed]

73. Zornberg, G.L.; Pope, H.G., Jr. Treatment of depression in bipolar disorder: New directions for research. J. Clin. Psychopharmacol. 1993, 13, 397-408. [CrossRef] [PubMed]

74. Fountoulakis, K.N.; Grunze, H.; Panagiotidis, P.; Kaprinis, G. Treatment of bipolar depression: An update. J. Affect. Disord. 2008, 109, 21-34. [CrossRef] [PubMed]

75. Cipriani, A.; Hawton, K.; Stockton, S.; Geddes, J.R. Lithium in the prevention of suicide in mood disorders: Updated systematic review and meta-analysis. BMJ 2013, 346, f3646. [CrossRef] [PubMed]

76. Calabrese, J.R.; Vieta, E.; Shelton, M.D. Latest maintenance data on lamotrigine in bipolar disorder. Eur. Neuropsychopharmacol. 2003, 13 (Suppl. 2), S57-S66. [CrossRef]

77. Goodwin, G.M.; Bowden, C.L.; Calabrese, J.R.; Grunze, H.; Kasper, S.; White, R.; Greene, P.; Leadbetter, R. A pooled analysis of 2 placebo-controlled 18-month trials of lamotrigine and lithium maintenance in bipolar I disorder. J. Clin. Psychiatry 2004, 65, 432-441. [CrossRef] [PubMed]

78. Crossley, N.A.; Bauer, M. Acceleration and augmentation of antidepressants with lithium for depressive disorders: Two meta-analyses of randomized, placebo-controlled trials. J. Clin. Psychiatry 2007, 68, 935-940. [CrossRef] [PubMed]

79. Inoue, T.; Abekawa, T.; Nakagawa, S.; Suzuki, K.; Tanaka, T.; Kitaichi, Y.; Boku, S.; Nakato, Y.; Toda, H.; Koyama, T. Long-term naturalistic follow-up of lithium augmentation: Relevance to bipolarity. J. Affect. Disord. 2011, 129, 64-67. [CrossRef] [PubMed]

80. Suppes, T.; Baldessarini, R.J.; Faedda, G.L.; Tohen, M. Risk of recurrence following discontinuation of lithium treatment in bipolar disorder. Arch. Gen. Psychiatry 1991, 48, 1082-1088. [CrossRef] [PubMed]

81. Grunze, H. Lithium in the acute treatment of bipolar disorders-A stocktaking. Eur. Arch. Psychiatry Clin. Neurosci. 2003, 253, 115-119. [CrossRef] [PubMed]

82. Van der Loos, M.L.; Mulder, P.; Hartong, E.G.; Blom, M.B.; Vergouwen, A.C.; van Noorden, M.S.; Timmermans, M.A.; Vieta, E.; Nolen, W.A. Long-term outcome of bipolar depressed patients receiving lamotrigine as add-on to lithium with the possibility of the addition of paroxetine in nonresponders: A randomized, placebo-controlled trial with a novel design. Bipolar Disord. 2011, 13, 111-117. [CrossRef] [PubMed]

83. Suppes, T.; Marangell, L.B.; Bernstein, I.H.; Kelly, D.I.; Fischer, E.G.; Zboyan, H.A.; Snow, D.E.; Martinez, M.; Al Jurdi, R.; Shivakumar, G.; et al. A single blind comparison of lithium and lamotrigine for the treatment of bipolar II depression. J. Affect. Disord. 2008, 111, 334-343. [CrossRef] [PubMed]

84. Calabrese, J.R.; Huffman, R.F.; White, R.L.; Edwards, S.; Thompson, T.R.; Ascher, J.A.; Monaghan, E.T.; Leadbetter, R.A. Lamotrigine in the acute treatment of bipolar depression: Results of five double-blind, placebo-controlled clinical trials. Bipolar Disord. 2008, 10, 323-333. [CrossRef] [PubMed]

85. Goodwin, G.M.; Haddad, P.M.; Ferrier, I.N.; Aronson, J.K.; Barnes, T.; Cipriani, A.; Coghill, D.R.; Fazel, S.; Geddes, J.R.; Grunze, H.; et al. Evidence-based guidelines for treating bipolar disorder: Revised third edition recommendations from the British Association for Psychopharmacology. J. Psychopharmacol. 2016, 30, 495-553. [CrossRef] [PubMed]

86. Fountoulakis, K.N.; Kasper, S.; Andreassen, O.; Blier, P.; Okasha, A.; Severus, E.; Versiani, M.; Tandon, R.; Moller, H.J.; Vieta, E. Efficacy of pharmacotherapy in bipolar disorder: A report by the WPA section on pharmacopsychiatry. Eur. Arch. Psychiatry Clin. Neurosci. 2012, 262 (Suppl. 1), 1-48. [CrossRef] [PubMed] 
87. Geddes, J.R.; Calabrese, J.R.; Goodwin, G.M. Lamotrigine for treatment of bipolar depression: Independent meta-analysis and meta-regression of individual patient data from five randomised trials. Br. J. Psychiatry 2009, 194, 4-9. [CrossRef] [PubMed]

88. Bond, D.J.; Lam, R.W.; Yatham, L.N. Divalproex sodium versus placebo in the treatment of acute bipolar depression: A systematic review and meta-analysis. J. Affect. Disord. 2010, 124, 228-234. [CrossRef] [PubMed]

89. Selle, V.; Schalkwijk, S.; Vazquez, G.H.; Baldessarini, R.J. Treatments for acute bipolar depression: Meta-analyses of placebo-controlled, monotherapy trials of anticonvulsants, lithium and antipsychotics. Pharmacopsychiatry 2014, 47, 43-52. [CrossRef] [PubMed]

90. Gyulai, L.; Bowden, C.L.; McElroy, S.L.; Calabrese, J.R.; Petty, F.; Swann, A.C.; Chou, J.C.; Wassef, A.; Risch, C.S.; Hirschfeld, R.M.; et al. Maintenance efficacy of divalproex in the prevention of bipolar depression. Neuropsychopharmacology 2003, 28, 1374-1382. [CrossRef] [PubMed]

91. Solomon, D.A.; Ryan, C.E.; Keitner, G.I.; Miller, I.W.; Shea, M.T.; Kazim, A.; Keller, M.B. A pilot study of lithium carbonate plus divalproex sodium for the continuation and maintenance treatment of patients with bipolar I disorder. J. Clin. Psychiatry 1997, 58, 95-99. [CrossRef] [PubMed]

92. Coxhead, N.; Silverstone, T.; Cookson, J. Carbamazepine versus lithium in the prophylaxis of bipolar affective disorder. Acta Psychiatr. Scand. 1992, 85, 114-118. [CrossRef] [PubMed]

93. Greil, W.; Ludwig-Mayerhofer, W.; Erazo, N.; Schochlin, C.; Schmidt, S.; Engel, R.R.; Czernik, A.; Giedke, H.; Muller-Oerlinghausen, B.; Osterheider, M.; et al. Lithium versus carbamazepine in the maintenance treatment of bipolar disorders-A randomised study. J. Affect. Disord. 1997, 43, 151-161. [CrossRef]

94. Greil, W.; Kleindienst, N.; Erazo, N.; Muller-Oerlinghausen, B. Differential response to lithium and carbamazepine in the prophylaxis of bipolar disorder. J. Clin. Psychopharmacol. 1998, 18, 455-460. [CrossRef] [PubMed]

95. Hartong, E.G.; Moleman, P.; Hoogduin, C.A.; Broekman, T.G.; Nolen, W.A. Prophylactic efficacy of lithium versus carbamazepine in treatment-naive bipolar patients. J. Clin. Psychiatry 2003, 64, 144-151. [CrossRef] [PubMed]

96. Watkins, S.E.; Callender, K.; Thomas, D.R.; Tidmarsh, S.F.; Shaw, D. The effect of carbamazepine and lithium on remission from affective illness. Br. J. Psychiatry 1987, 150, 180-182. [CrossRef] [PubMed]

97. Denicoff, K.D.; Smith-Jackson, E.E.; Disney, E.R.; Ali, S.O.; Leverich, G.S.; Post, R.M. Comparative prophylactic efficacy of lithium, carbamazepine, and the combination in bipolar disorder. J. Clin. Psychiatry 1997, 58, 470-478. [CrossRef] [PubMed]

98. Grande, I.; Berk, M.; Birmaher, B.; Vieta, E. Bipolar disorder. Lancet 2016, 387, 1561-1572. [CrossRef]

99. Sun, N.; Lei, L.; Wang, Y.; Yang, C.; Liu, Z.; Li, X.; Zhang, K. Preliminary comparison of plasma notch-associated microRNA-34b and $-34 \mathrm{c}$ levels in drug naive, first episode depressed patients and healthy controls. J. Affect. Disord. 2016, 194, 109-114. [CrossRef] [PubMed]

100. Baudry, A.; Mouillet-Richard, S.; Schneider, B.; Launay, J.-M.; Kellermann, O. miR-16 targets the serotonin transporter: A new facet for adaptive responses to antidepressants. Science 2010, 329, 1537-1541. [CrossRef] [PubMed]

101. Lopez, J.P.; Lim, R.; Cruceanu, C.; Crapper, L.; Fasano, C.; Labonte, B.; Maussion, G.; Yang, J.P.; Yerko, V.; Vigneault, E. miR-1202 is a primate-specific and brain-enriched microRNA involved in major depression and antidepressant treatment. Nat. Med. 2014, 20, 764-768. [CrossRef] [PubMed]

102. Blazquez, A.; Gasso, P.; Mas, S.; Plana, M.T.; Lafuente, A.; Lazaro, L. One-Year Follow-up of Children and Adolescents with Major Depressive Disorder: Relationship between Clinical Variables and Abcb1 Gene Polymorphisms. Pharmacopsychiatry 2016, 49, 248-253. [CrossRef] [PubMed]

103. Taranu, A.; Asmar, K.E.; Colle, R.; Ferreri, F.; Polosan, M.; David, D.; Becquemont, L.; Corruble, E.; Verstuyft, C. The Catechol-O-methyltransferase Val(108/158)Met Genetic Polymorphism cannot be Recommended as a Biomarker for the Prediction of Venlafaxine Efficacy in Patients Treated in Psychiatric Settings. Basic Clin. Pharmacol. Toxicol. 2017, 121, 435-441. [CrossRef] [PubMed] 
104. Oedegaard, K.J.; Alda, M.; Anand, A.; Andreassen, O.A.; Balaraman, Y.; Berrettini, W.H.; Bhattacharjee, A.; Brennand, K.J.; Burdick, K.E.; Calabrese, J.R.; et al. The Pharmacogenomics of Bipolar Disorder study (PGBD): Identification of genes for lithium response in a prospective sample. BMC Psychiatry 2016, 16, 129. [CrossRef] [PubMed]

105. Mayberg, H.S.; Brannan, S.K.; Mahurin, R.K.; Jerabek, P.A.; Brickman, J.S.; Tekell, J.L.; Silva, J.A.; McGinnis, S.; Glass, T.G.; Martin, C.C.; et al. Cingulate function in depression: A potential predictor of treatment response. Neuroreport 1997, 8, 1057-1061. [CrossRef] [PubMed]

106. Kennedy, S.H.; Evans, K.R.; Kruger, S.; Mayberg, H.S.; Meyer, J.H.; McCann, S.; Arifuzzman, A.I.; Houle, S.; Vaccarino, F.J. Changes in regional brain glucose metabolism measured with positron emission tomography after paroxetine treatment of major depression. Am. J. Psychiatry 2001, 158, 899-905. [CrossRef] [PubMed]

107. Lisiecka, D.; Meisenzahl, E.; Scheuerecker, J.; Schoepf, V.; Whitty, P.; Chaney, A.; Moeller, H.-J.; Wiesmann, M.; Frodl, T. Neural correlates of treatment outcome in major depression. Int. J. Neuropsychopharmacol. 2011, 14, 521-534. [CrossRef] [PubMed]

108. Williams, L.M.; Korgaonkar, M.S.; Song, Y.C.; Paton, R.; Eagles, S.; Goldstein-Piekarski, A.; Grieve, S.M.; Harris, A.W.; Usherwood, T.; Etkin, A. Amygdala reactivity to emotional faces in the prediction of general and medication-specific responses to antidepressant treatment in the randomized iSPOT-D trial. Neuropsychopharmacology 2015, 40, 2398. [CrossRef] [PubMed]

109. Uher, R.; Tansey, K.E.; Dew, T.; Maier, W.; Mors, O.; Hauser, J.; Dernovsek, M.Z.; Henigsberg, N.; Souery, D.; Farmer, A. An inflammatory biomarker as a differential predictor of outcome of depression treatment with escitalopram and nortriptyline. Am. J. Psychiatry 2014, 171, 1278-1286. [CrossRef] [PubMed]

110. Benes, F.M.; Matzilevich, D.; Burke, R.E.; Walsh, J. The expression of proapoptosis genes is increased in bipolar disorder, but not in schizophrenia. Mol. Psychiatry 2006, 11, 241-251. [CrossRef] [PubMed]

111. Andreazza, A.C.; Kauer-Sant'anna, M.; Frey, B.N.; Bond, D.J.; Kapczinski, F.; Young, L.T.; Yatham, L.N. Oxidative stress markers in bipolar disorder: A meta-analysis. J. Affect. Disord. 2008, 111, 135-144. [CrossRef] [PubMed]

112. Murray, J.; Taylor, S.W.; Zhang, B.; Ghosh, S.S.; Capaldi, R.A. Oxidative damage to mitochondrial complex I due to peroxynitrite: Identification of reactive tyrosines by mass spectrometry. J. Biol. Chem. 2003, 278, 37223-37230. [CrossRef] [PubMed]

(c) 2017 by the authors. Licensee MDPI, Basel, Switzerland. This article is an open access article distributed under the terms and conditions of the Creative Commons Attribution (CC BY) license (http://creativecommons.org/licenses/by/4.0/). 